\title{
Research on the Cultivation of New Professional Farmers in Hainan Based on Supply Side Factors Sun Tieyu
}

Hainan Radio and TV University, Haikou, Hainan, China

22720068@qq.com

Keywords: Supply-side structural reform in agriculture, New professional farmers, Farmers cultivation.

\begin{abstract}
The 19th Plenary Session of the Party explicitly proposed to build a prosperous, democratic, civilized, harmonious, beautiful and powerful socialist country by the middle of this century. The construction and realization of agricultural modernization require a new type of professional farmers. Different from traditional farmers, new professional farmer is a new generation of farmers, with knowledge, technology, management, responsibility and social status. We call them " professional farmer", it' s not just due to their high comprehensive quality, good at production or with a high level of management, the more important is innovation entrepreneurial ability, which can help local farmers to get rich, become the bussiness entity of production operation, professional skilled or professional service. Based on the income of Hainan farmers, this article analyzes the necessity of cultivating a new type of professional farmer in Hainan, puts forward the connotation of supply-side structural reform in cultivating new professional farmers, and elaborates what role the government will play and the task that government needs to do in the process of cultivating professional farmers.
\end{abstract}

\section{基于供给侧因素的海南新型职业农民培养问题研究}

\author{
孙铁玉 \\ 海南广播电视大学, 海口, 海南, 中国 \\ 22720068@qq.com
}

关键词：农业供给侧结构性改革；新型职业农民；农民培育

中文摘要. 党的十九大明确提出在本世纪中叶建成富强、民主、文明、和谐、美丽的社会主 义现代化强国。农业现代化的建设与实现，需要职业化的新型农民。区别于传统农民，新型 职业农民是 “有文化、懂技术、会经营、负责任、有地位” 的新一代农民，赋予其 “职业人” 这一特征，不仅是因为综合素质好、生产技能强、经营管理水平高，更为重要的是具有创新 创业能力，可以带动当地农民致富，成为生产经营型、专业技能型或专业服务型的生产和经 营主体。本文从海南农民收入分析海南新型职业农民培育的必要性, 提出新型职业农民培育 供给侧结构性改革的内涵，阐述在新型职业农民培育中政府担当的角色及任务。

1. 引言

党的十九大指出, 我国经济已由高速增长阶段转向质量发展阶段, 正处在转变发展方式、 优化经济结构、转换增长动力的攻关期。深化供给侧结构性改革是实现现代化经济体系战略 
目标之一。农业供给侧结构性改革的目的是通过改变和提升现有的农业生产方式和生产过程, 提升农业质量、效益和市场竞争力, 从根源上, 需要培育和发展新型农业生产主体和经营主 体并不断提高主体的发展质量。

\section{2. 从海南农民收入看新型职业农民培育}

得天独厚的生态环境、自然资源和一流的光、热、水条件，使海南热带农业生产区位优 势凸显, 为农民收入平稳增长奠定了良好的经济环境。至2013年, 与全国平均水平相比, 海 南农民收入中农业经营收入占比一直处于较高水平。

但近几年，从外部环境来看，海南农业发展仍以传统的数量型增长为主，受资源约束和 环境保护的压力, 出现了农业生产低效规模过大、生产成本上升、加工能力低、抗自然风险 和人为风险能力弱等问题。2014－2017年，海南农民收入增速逐渐回落。据统计，2017年一 季度, 经营净收入中第一产业收入同比下降 $4 \%$, 特别是农业经营净收入下降幅度较大, 同比 下降 $17.7 \%$ 。与全国农民平均收入相比，一季度海南农民收入低于全国农民收入459元。海南 农民收入增速回落的现状折射出海南农业发展中经营主体实力不强, 海南农民收入已经进入 发展新常态。

海南省有近半数人口居住在农村。根据《2016年海南省国民经济和社会发展统计公报》 统计：2016年末海南省常住人口917.13万人，农村人口比重为 $43.22 \%$ 。全省从业人员 562.94 万人, 其中乡村从业人员 314.06 万人, 占农村人口总数的 $79.23 \%$ 。另一方面, 海南又是热带 农业大省。2017年5月3日召开的全省农业工作会议指出：2016年海南省农业增加值达到 1000.18 亿元, 增长 $4.2 \%$, 增速排名全国前列, 其中热带特色高效农业产值占农业总产值的比 重达70\%，体现了热带特色高效农业在海南农业全局发展中的重要地位和作用。

“深入推进农业供给侧结构性改革，做强做精做优热带特色高效农业”离不开新型职业农 民这一现代农业“职业人”。2013年，海南省在海口市、澄迈县、万宁市开启了新型职业农民 培育工程，经过近四年的发展，新型职业农民培育工程为解决海南农村“谁来种地”，促进海 南从传统农业向现代热带农业转变, 培养了一批素质和技能较高的农民, 但在培育数量与质 量上与建设“一支高素质农业生产经营者队伍”仍有较大差距。

\section{3. 新型职业农民培育的供给侧结构性改革的内涵}

\section{1 新型职业农民培育的供给侧改革的逻辑起点是农民对教育培训的需求}

新型职业农民培育是农民的需求，更要服务于农民。由于新型职业农民培训需求具有多 样性、差异性、变动性、隐含性特征, 农民教育培训呈现多层次、多类型、多样化的需求特 点。因此, 根据经济学有效需求理论, 需求决定供给, 新型职业农民供给侧改革, 需要从调 研分析农民教育培训的需求开始（包括农民的性别、年龄、文化程度等个体因素，从事农业 背景、种植养殖经营模式、农机服务方式等农业生产经营因素, 子女是否学农或从事农业生 产及是否有扩大农业生产愿望等农业生产意愿因素以及对培训认知、培训时间、培训类型等 教育培训因素等），通过满足农民对教育培训需求的偏好，才能实现新型职业农民教育培训 供给和需求的均衡, 实现精准培育。为提高新型职业农民教育培训的针对性和实效性, 满足 新型职业农民终身化学习需要, 应建立参训农民资料库, 通过对参训农民的年龄结构、学历 水平、种养植产业及其规模、生产经营收入、发展意向、农产品的产供销信息及参训情况、 成效等资源的电子化管理，整体把握新型职业农民培育前、培育中以及培育后的各项工作。

\section{2 新型职业农民培育的供给侧改革的核心是调结构、转方式、强体系}

海南新型职业农民教育培训中普遍存在的“脱农”现象，说明教育培训缺乏针对性、规范 性、有效性, 精准程度不高。基于当前海南经济社会发展现状, 推进农业供给侧结构性改革 
必须做好“转型、创新和改革”等方面的工作。新型职业农民教育培训需要从供给端“调结构、 转方式、强体系”, 即调整教育培训资源结构、转变传统教育培训模式、增强教育培训的保障 机制体系。

\section{3 新型职业农民培育的供给侧改革的终点是教育培训的质量}

农业供给侧结构性改革目的是要改变农产品的供给品种、品质和数量, 满足需求, 刺激 经济。基于此, 通过培育职业农民队伍, 提高职业农民队伍的素养和质量, 为发展海南高效 农业产业, 培育优势产业带, 构建起热带特色高效农业产业体系, 实现海南农业现代化建设 和农业持续健康发展提供坚实的人力基础和保障, 这也是检验和考核新型职农民教育培训的 标准。

\section{4. 政府在新型职业农民培育供给侧改革中的任务}

新型职业农民教育培训的公益属性, 加之市场经济发展中存在的公共产品供给困境、信 息不对称等问题，在农民职业教育中都形成了以政府为主导的农民教育供给主体体系的格局。 借鉴国外农民职业教育供给模式, 结合海南新型职业农民教育培训现状, 政府在新型职业农 民培育供给侧改革中应做好以下几方面的工作。

\section{1 制定新型职业农民教育培训的政策法规}

虽然我国的《职业教育法》对职业教育的发展做出了基本规定，《“十三五”全国新型职 业农民培育发展规划》为新型职业农民培育指明了方向, 但保障新型职业农民培育有效性的 法律基础尚属空白。考察农民职业教育模式成功的国家经验, 都是在依法治农之下建立从供 给主体、形式、内容到保障等完备内容的农民教育立法、监督体系。例如德国于1996年颁布 实施了《职业教育法》，确立了“双元制”的农民农业学历教育体制; 英国于1982年颁布并于 1987年进一步修订了《农业培训局法》；日本于1883年和1977年先后颁布了《农学校通则》 和《农业改良促进法》; 韩国政府先后于1980年和1990年制定了《农渔民后继者育成基金法》 和《农渔民发展特别措施法》。这些法律法规的颁布实施不断完善和强化了农民职业教育与 技术培训, 为培养农业后继者和专业农户提供了法律保证。因此, 我国应当建立成熟的农民 教育法律体系、政策和供给保障措施, 通过立法来完善农民职业教育体系, 特别是海南省要 针对本省农业机械化程度不高, 农场规模相对较小, 农业生产效率较低, 加之各区域自然地 理环境、资源禀赋、经济发展水平不同的情况, 出台海南省地方性新型职业农民培育政策法 规, 如完善土地流转制度, 让农民安心规模化生产经营; 新型职业农民的认定标准和申报流 程; 新型职业农民学历提升和终身教育项目; 新型职业农民教育培训的后续服务保障等, 并 在土地、税收、金融等方面给予倾斜或优惠政策, 保证新型职业农民培育对象的自愿参与和 长效化的教育培训。这不仅是依法治农的需要, 也是海南在热带特色高效农业发展中, 保证 人力、物力、财力的投入，造就和培养农村、农业发展所亟需的实用人才的必然要求。

\section{2 加大对新型职业农民教育培训的投入}

2016年海南省新型职业农民培育工程专项资金为 2124 万元 (其中中央财政资金 1124 万元， 省级配套资金 1000 万元），培育新型职业农民9390人，人均培育经费仅为 2261.98 元。以上数 据说明：第一，我国的新型职业农民培育工程开启较晚, 教育培训资金的来源渠道单一, 主 要以中央财政资金和地方政府的配套资金为主。第二，新型职业农民教育培训资金投入和发 达国家相比还有待提高。例如美国政府为了推动农业教育，自1995年以来，每年以 $8 \%$ 左右的 年率逐年递增农民教育经费投入，从2002年至2007年新增农业补贴519亿美元，总计1185亿美 元; 日本规定政府承担农业技术普及培训事业所需经费一半; 澳大利亚政府为鼓励企业开办 农业职业培训机构, 提供20\%-30\%培训经费补助。因此, 在加大政府对新型职业农民教育 培训投入的基础上，应形成多元化的新型职业农民教育培训投资体系，以资金补占、减免税 
收等方式鼓励并发挥企业、社会组织、金融机构民间资金的投入、补充作用; 通过建立新型 职业农民教育基金, 并纳入财政预算, 相应增加农业产业投入、补贴和贷款额度; 加大新型 职业农民的项目扶持、资金扶持、保障扶持、融资扶持，以拓宽他们农业发展资金渠道，这 也是提高农民素质、培养新型职业农民的现实选择。

\section{3 构建以教促农的农民教育供给体系}

第一，要建立形式多样的农民教育管理机和培训组织。根据2016年海南省新型职业农民 培育工程实施方案, 承担海南新型职业农民教育培训主要是通过各市县相关农业部门招标社 会培训机构为主, 没有形成完备的、多层次、多元化的农民培育机构网络。纵观发达国家新 型职业农民培育的成功, 离不开农业科教体系的建立和完善。例如美国已形成了以政府为主 导, 以农业院校为基地, 以社会培训机构为补充, 农业教育、科研、推广相结合的农民职业 化培训体系，以保证新型职业农民教育培训中，即向农民提供实际生产的劳动技术和经验， 使其掌握农业生产知识, 又为农民提供综合科技知识。再如澳大利亚各级政府非常支持农民 职业教育培训, 国家专门成立了教育科学培训部(DEST)、国家职业教育研究中心(NCVER)等 政府部门对教育培训进行战略定位、支持及管理, 在农、渔、林业部的主要职能内添设“指导 并开展农民培训, 并对不同农业行业设立了能力水平标准”等职能, 将农民培育提升到保证国

\section{民经济高质量、高效率运作的高度来认识。}

第二，创新新型职业农民培育的有效模式。按照海南当前农村职业教育与培训现状，可 以借鉴和学习日本的农业职业教育体系: 建立政府统筹规划、农业部门与相关部门分工指导 协作，教育系统为主体，民间团体和社会组织相互配合的、多层次的立体化教育体系，实现 理论与实践相统一、学历教育与终身教育相结合的长效培育模式。

第三，要建立教育质量监督机制。为了保证和提高新型职业农民培训的质量和农民教育 的效益, 首先要建立与之配套的、切实可行的考核和认证制度。鉴于海南农民文化教育层次 的差异化，因地制宜以种植、养殖农产品，现代农业生产操作技术或技能，现代农业生产与 管理的方案、措施、手段等“农业生产成果”制定各种等级、划分多种类型的考核目标，从农 民综合素质、农业生产或经营规模、科技含量、农业经济效益、服务水平等方面综合考量新 型职业农民的认证标准, 将新型职业农民分为一二三（或初、中、高）不同等级, 以实现政 府扶持界定明晰的对象，真正做到精准培育; 其次要发挥“互联网+”作用，特别是要遴选既懂 得教育理论、方法和现代化教育信息技术，又有较强农业生产经营经验的教师充实到农民职 业教育或新型职业农民教育培训的师资建设中, 建立线上+线下学习支持服务与教学质量监督 评价体系; 最后, 为了达到新型职业农民培养目标的需求, 推动农民职业教育的质量提升, 应建立激励机制，例如可以借鉴英国设立的“国家培训奖”，用以奖励在农业技术培训方面有 突出贡献的组织机构。

\section{5. 结束语}

发达国家农民职业教育的发展，形成了包括农民在内的多赢的利益格局，也为我国新型 职业农民教育培训提供了立法保障、管理协调机制、资格准入制度、培训经费等方面的经验。

2017年中央一号文件指出, 要深入推进农业供给侧结构性改革, 加快培育农业农村发展 新动能。新型职业农民教育培训作为推动农业供给侧结构性改革的重要抓手, 在当前我国农 业劳动力缺失严重, 教育资源分配不均衡的情况下, 通过构建符合各个地区自身农业发展需 要的新型职业农民的培育模式, 提供服务农业发展、农村繁荣的准公共产品任重而道远。 


\section{致谢}

本文为海南省高等学校教育教学改革研究资助项目《海南新型职业农民培养模式研究》 （项目编号：Hnjg2017-50）的阶段性成果之一。

\section{References}

[1] LU Cai-lan,Analysis of Developing New Agricultural Management Entities Based Supply-Side Factors,Journal of Yangzhou College of Education, Vol.35,pp. 46-48,2015.

[2] S. K. Goyal,GUO Xiao-ru,The Experience and Enlightenment of Foreign New Professional Farmers Training,Journal of Jilin Teachers Institute of Engineering and Technology, Vol. 31, pp. 46-48,2015.

[3] Wu Yixiong,On the Development of Agricultural Informatization and the Cultivation of New Type of Professional Farmers-The Case of Hu'nan Province, Vocational and Technical Education,Vol.36,pp.49-54.2015. 